\title{
Аналіз існуючих підходів до реабілітаційного процесу осіб із проявами «офісного синдрому»
}

\author{
УдК: 316.343.655:613.65+615.825
}

\section{і. В. Онопрієнко}

Національний університет фізичного виховання і спорту України, Київ, Україна

\begin{abstract}
Анотація. Мета. На основі аналізу сучасних наукових та клінічних досліджень проаналізувати існуючі підходи до процесу фізичної терапії осіб працездатного віку із проявами «офісного синдрому». Методи. Аналіз та узагальнення вітчизняних та зарубіжних даних спеціальної науково-методичної літератури, що стосуються основних підходів до процесу фізичної терапії проявів «офісного синдрому» у осіб працездатного віку; синтез та узагальнення. Результати. Проведений аналіз останніх наукових робіт показав, що існує багато досліджень, які описують фізичні та функціональні показники працівників, котрі ведуть малорухомий спосіб життя та страждають різними проявами «офісного синдрому». Як правило, це патологія опорно-рухового апарату, периферичної нервової системи та шлунково-кишкового тракту. Відсутні програми фізіотерапевтичних втручань, що мають комплексний характер реабілітації проявів синдрому. Висновки. Донедавна було виконано численні дослідження вітчизняними та зарубіжними вченими, які були присвячені побудові та ефективності реабілітаційного процесу офісних працівників різних вікових груп з різними проявами офісного синдрому». Та в жодному з них не описано комплексну програму реабілітаційного втручання для осіб, які страждають на прояви «офісного синдрому».

Ключові слова: фізична терапія, реабілітація, офісний синдром.
\end{abstract}

Analysis of existing approaches to the rehabilitation process of the persons with "office syndrome" manifestations

I. V. Onopriienko

National University of Physical Education and Sport of Ukraine

Abstract. Objective. To analyze the existing approaches to the physical therapy process of the individuals of working age with manifestations of the "office syndrome» on the basis of the analysis of modern scientific and clinical studies. Methods. Analysis and generalization of national and foreign data of special scientific and methodical literature concerning the basic approaches to the process of physical therapy of «office syndrome» manifestations in the individuals of working age, synthesis and generalization. Results. Analysis of recent scientific works has shown that there are many studies that describe the physical and functional characteristics of sedentary office workers, who are suffering from various manifestations of the "office syndrome». Typically, this is the pathology of the motor system, peripheral nervous system and gastrointestinal tract. There are no programs of physiotherapy interventions having a complex character of rehabilitation of syndrome manifestations. Conclusions. Until recently, numerous studies have been carried out by national and foreign scientists devoted to the development and effectiveness of the rehabilitation process of office workers of different age groups with different manifestations of this syndrome. But none of them describes a comprehensive rehabilitation program for people suffering from «office syndrome».

Key words: physical therapy, rehabilitation, office syndrome.

Постановка проблеми. В умовах сучасного виробництва збільшується кількість офрісних працівників, котрі становлять близько 2 млн осіб в Україні. При цьому рівень захворюваності серед них у 1,4-1,6 раза перевищує середній показник по Україні [4]. Однією з причин зростання цього показника $\epsilon$ гіподинамія та прогресуючі патології опорно-рухового апарату (ОРА), 
серцево-судинної системи, нервової системи та обміну речовин.

Серед великої кількості населення України, що піддається негативному впливу фракторів зовнішнього середовища та малорухомому способу життя, чимала частка саме офрісних працівників. Це пов'язано з тим, що вони більшу частину денного часу витрачають на роботу і мало часу проводять за заняттями оздоровчою руховою активністю, що з часом може переходити в цілий ряд патологій: кістково-м'язові порушення та болі, порушення артеріального тиску (AT), рухові порушення периферичних нервів, порушення обміну речовин та зору. Найбільший відсоток захворюваності у такого контингенту припадає саме на патологію OPA та зокрема на вертеброгенну патологію [10].

Дегенеративно-дистрофрічні захворювання OPA представляють серйозну соціальну проблему, яка визначається зростанням показників захворюваності, високим рівнем інвалідності, особливо в осіб працездатного віку, величезними витратами на лікування та відшкодування тимчасової або стійкої втрати працездатності. На надзвичайну важливість проблеми вказує і той факт, що первинна інвалідність унаслідок патології OPA у 2016 р. зросла порівняно з 2015 р. [2]. При цьому значне місце серед патології офрісних працівників займають порушення структур та фрункцій ОРА. Але не в усіх випадках у офрісних працівників вдається проводити вчасні та адекватні реабілітаційні заходи, та не в усіх випадках саме цей контингент $є$ достатньо мотивованим до занять руховою активністю.

Аналіз останніх досліджень. У офісних працівників з розвитком інформаційних технологій, автоматизації праці, гіподинамії і все більшої стереотипності рухів офрісних служб з'явився новий симптомокомплекс, етіологічно пов'язаний із фракторами ризику на робочому місці.

Стан осіб похилого віку та літніх людей, котрі працюють в офрісі, має бути керований за допомогою різних програм управління охороною здоров'я та забезпечити активне старіння суспільства як [10].

Колективом авторів було досліджено фрізичний стан працівників середнього віку в Республіці Корея за категорією праці (офрісна робота порівняно з виробництвом). Загалом з 2007 по 2008 р. було обстежено суб'єктивний рухової стан, стан фрізичного навантаження, статус куріння та статус рухової активності, серцево-судинної витривалості, м'язової сили, м'язової витривалості, гнучкості, рівня рефлексів і реакції 3650 працівників віком $\geq 50$ років (робота на виробництві, $\mathrm{n}=2615$; офрісна робота, $\mathrm{n}=1,035)$ з восьми географрічних районів. Суб'єктивно, фрізичний стан і рівень рухової активності тих, хто працює в офрісі, був кращий, ніж у працівників виробництва. Офісні працівники мали кращу серцево-судинну витривалість, м'язову силу, м'язову витривалість, рефрлекси і реакції. Проте працівники виробництва були більш гнучкими, ніж офрісні працівники.

За даними T. R. Waters, R. B. Dick [12], тривале стояння на роботі пов'язане з низкою потенційно серйозних наслідків для здоров'я, таких, як біль у попереку та в ногах, серцевосудинні проблеми, втома, дискомфорт та наслідки для здоров'я, пов'язані з вагітністю у жінок. Авторами виконано дослідження, в основі якого було вивчення взаємозв'язку між цими показниками та кількістю часу, витраченого на постійне перебування на роботі. Автори наводять достатньо доказів, які свідчать про те, що тривале перебування на роботі призводить до несприятливих наслідків для здоров'я.

B роботі $\mathrm{P}$. Nejati et al. [10] визначено кількісні постуральні зміни біомеханіки голови, шийного і грудного відділів хребта і плечей в офрісних працівників (під час сидіння прямо та під час роботи за комп'ютером) для встановлення, чи мають особи, які страждають від болю у шийному відділі хребта, неправильну поставу порівняно 3 особами без больових відчуттів у цьому відділі хреба.

J. Sethi et al. [8] виявили вплив показників індексу маси тіла на дискомфорти ОРА, що пов'язані з роботою, та профресійне напруження під час роботи за комп'ютером в розробленій ергономічній установці [8]. Автори довели, що існує значний вплив індексу маси тіла на підвищення рівня пов'язаного з роботою опорно-рухового дискомфорту і професійно-психосоціального стресу серед працівників, які тривалий час проводять за комп'ютером у розробленій ергономічній установці.

Протягом робочого дня, який становить 8 год., більшу частину часу офрісні працівники перебувають безпосередньо за комп'ютером, або на своєму робочому місці, піддаючись при цьому впливу всього спектра негативних проявів, що були перераховані вище та включені до кластерного патологічного стану, що отримав назву «офрісний синдром» - це складний симптомокомплекс, який включає в себе порушення, що проявляються в різних органах і системах, а також розвивається в офрісних службах у зв'язку з порушенням їх діяльності.

Мета дослідження - на основі аналізу сучасних наукових та клінічних досліджень 
проаналізувати існуючі підходи до процесу фрізичної терапії осіб із проявами «офрісного синдрому».

Методи дослідження: аналіз та узагальнення вітчизняних та зарубіжних даних спеціальної науково-методичної літератури, що стосуються основних підходів до процесу фрізичної терапії проявів «офісного синдрому», синтез та узагальнення.

Результати дослідження та їх обговорення. Аналіз останніх наукових робіт показав, що існує багато досліджень, які описують фрізичні та функціональні показники працівників, які ведуть малорухомий спосіб життя та страждають різними проявами «офрісного синдрому». Зазвичай, це патологія ОРА, периферійної нервової системи та шлунково-кишкового тракту. При цьому цей патологічний стан вражає як чоловіків, так і жінок, та має комбінований характер. Проте відсутні розроблені програми фрізіотерапевтичних втручань, що мають комплексний характер реабілітації проявів синдрому.

Під час розроблення реабілітаційних програм, що мають принципово новий характер або вирішують не вирішені завдання фрізичної терапії нових патологічних станів, не занесених до жодних класиорікаторів, прийняття рішень $€$ досить складним процесом, що вимагає використання надійної інфоомації про ефективність та високу доказовість різних засобів фрізичної реабілітації. Складність в їх виборі посилюється, з одного боку, величезним потоком публікацій, а з іншого - «моральним старінням» інфоормації. Все це створює труднощі для критичного її осмислення у виборі правильного рішення щодо обраної реабілітаційної тактики ведення пацієнтів. Тому нерідко реабілітаційні програми $\epsilon$ мало обгрунтованими, з низькою ефективністю, або дублюють одна одну, при цьому наводять принципово нові дані щодо нових порушень або патології [1].

Це особливо стосується тих патологічних станів, порушень структур та функцій тіла, що стали актуальними протягом останніх десяти років. До цього числа можна віднести комплексне поняття «офрісний синдром». Донедавна було виконано численні дослідження вітчизняними та зарубіжними вченими, які були присвячені побудові та есрективності реабілітаційного процесу офрісних працівників різних вікових груп з різними проявами цього синдрому. При цьому в жодній із публікацій не наведено інших симптомів чи проявів «офрісного синдрому» або не описано комплексність та мультидисциплінарність реабілітаційного підходу.

Так, в роботі R. Sihawong et al. [9] запропоновано програму вправ, спрямовану на збільшення показників гнучкості і витривалості, зменшення частоти та періодичності болю в шийному відділі хребта в офрісних працівників, що тривала 12 міс. У дослідженні взяли участь особи 18-55 років із зниженою амплітудою згинання шиї та витривалістю м'язів шиї, які працювали повний робочий день. Основній групі було призначено програму вправ на розтягування і витривалість. Програма складалася 3 вправ на розтягування для чотирьох м'язів шиї, кожна з яких виконувалася протягом 30 с, двічі на робочий день. Тренування на витривалість складалося з 10 повторів стійких утримань м'язів-згиначів шиї, двічі на тиждень протягом 12 міс. Учасники тренувань отримували нагадування через мобільний телефрон кожний робочий день протягом перших 3 міс., і записували виконання занять у щоденнику. Контрольна група, окрім звичайної медичної допомоги, не отримувала будь-яких призначених вправ. Загалом дослідження завершили 534 учасники (94\%). За 12 міс. 32 з 267 (12 \%) учасників групи втручання і 72 з 270 (27 \%) учасників контрольної групи повідомляли про епізоди загострення болю в ділянці шиї. Дотримання вправ (відсоток прописаних завершених сеансів) для основної групи становило від 30 до $34 \%$ для вправ на розтягування і $57 \%$ - для вправ на витривалість. Групи істотно не відрізнялися за зміною показників витривалості м'язів-згиначів шиї, оскільки ефекти взаємодії були незначними. Але у виконаному дослідженні автори не наводять даних щодо наявності інших проявів «офрісного синдрому» у обстежуваних та не пропонують засоби профрілактики/фрізичної терапії.

У дослідженні В. В. Кормільцева [7] за допомогою аналізу варіабельності серцевого ритму експериментально підтверджено ефективність програми фрізичної реабілітації попереково-крижового остеохондрозу у офрісних працівників. У дослідженні взяли участь 60 осіб віком 38,6 року. Показано позитивний вплив на характер серцевого ритму програми фрізичної реабілітації з елементами медфіту, лікувального масажу, гідрокінезитерапії та засобів, запозичених з оздоровчого фрітнесу. Встановлено, що позитивний вплив програми залежить від адекватно підібраних засобів і методів відновлення функціонального стану. Компоненти розробленої програми фрізичної реабілітації, що використовуються при болю в поперековому відділі хребта в стадії ремісії, відрізняються за інтенсивністю, обсягом і напрямком впливу на окремі групи м'язів, залежно від розташування ураженого сегмента, показників функціональних умов, характеру i тривалості виникнення захворювання. Аналіз 
показників варіабельності серцевого ритму був статистично значущим поліпшенням рівня напруженості в регуляторних системах органу обох досліджуваних груп. Ці дані також вказують на те, що результати реабілітації в контрольній групі, де використовують стандартний реабілітаційний комплекс, загалом мають позитивний ефект, але менш ефективні, ніж у випадку запропонованої нами програми реабілітації. Проте, робота автора була виконана без врахування порушень за Міжнародною класифікацією функціонування (ICF) та стосується лише порушень у поперековому відділі хребта на віддалених фразах реабілітації.

G. Seong-Uk, L. Byoung-Heе [6] у своєму дослідженні визначили вплив мануальної терапії на рівень болю в плечах у офісних працівників. Суб'єктами дослідження були 38 офісних працівників, які були випадковим чином розподілені на дві групи: група мануальної терапії (19 осіб) і група вправ на стабілізацію плеча (19 осіб). У всіх суб'єктів оцінювали больовий поріг у верхній, середній та нижній частинах трапецієподібного м'яза з обох боків. Мануальна терапія, яку використовували в дослідженні, була розроблена для включення мобілізації м'яких тканин, грудної мобілізації. Обидві групи пройшли підготовку двох 40-хвилинних сеансів на тиждень протягом 6 тиж. Після втручання обидві групи показали значне посилення порогових значень больових відчуттів у верхній, середній та нижній частинах трапецієподібного м'яза з обох сторін. Група мануальної терапії показала статистично більші покращення, ніж група тренувань стабілізації плеча з обох боків: ліва верхня частина трапеції, середня частина трапеції з обох сторін і права нижня частина трапеції. Результати цього дослідження дозволяють припустити, що мануальна терапія при болю в плечі $є$ доцільною та придатною для офрісних працівників і може бути корисною в клінічній реабілітації.

Можна не сумніватися, що ймовірність розвитку больового синдрому, ступінь його вираженості, тривалість перебігу, ефективність терапії, що проводиться, значною мірою будуть визначатися емоційним станом хворого, зокрема наявністю тривожних, депресивних порушень [3]. Цілком очікувано, що працівники, які проводять у вимушеному фріксованому положенні перед екраном монітора тривалий час, відчувають суттєвий дефріцит фрізичних навантажень при мінімальній вираженості навантажень динамічних, змушені виконувати стереотипні рухи (робота 3 клавіатурою, комп'ютерною мишею і ін.), виявляються дуже уразливими щодо розвитку больових синдромом різної локалізації. Характер трудової діяльності, хронічні стресові ситуації також сприяють їх реалізації. Лікування даного контингенту пацієнтів повинно включати в себе цілий ряд напрямків терапевтичного впливу. Водночас часто першочерговим завданням надання медичної допомоги даному контингенту пацієнтів є своєчасне усунення або зменшення вираженості больового синдрому з метою максимально раннього початку проведення реабілітаційних заходів, попередження хронізації больового синдрому, підвищення якості життя хворого. Проблема проведення адекватної терапії утруднена наявністю значної кількості лікарських препаратів, що мають, з одного боку, достатню ефективність, а з іншого володіють широким спектром різноманітних небажаних побічних ефректів.

У дослідженні C. Maruyama et al. [5] описано ефективну програму запобігання метаболічних захворювань шляхом зміни способу життя у офрісних працівників. Автори досліджували вплив програми модифікації способу життя на програму рухової активності та харчування (LiSM10), на метаболічні параметри у чоловіків японського походження середнього віку. Сто чоловіків, офісних працівників, віком від 30 до 59 років, з факторами ризику метаболічного синдрому, були випадковим чином розподілені на контрольну групу без лікування (n= 49), і групу LiSM (n = 52). Група LiSM пройшла індивідуальне оцінювання та спільні постановки цілей, засновані на прийомі їжі та руховій активності, після чого щомісяця було проведено дві індивідуальні консультації з зареєстрованим дієтологом та фрізичним тренером. Групі LiSM було запропоновано вносити поточні цільові прийоми їжі та дані крокоміра на веб-сайти самоконтролю протягом усього періоду дослідження. Звичайні прийоми групи харчових продуктів істотно змінилися в групі LiSM, показавши покращення в 14 антропометричних та біохімічних параметрах, що сприяють міжгруповим відмінностям у масі тіла, індексі маси тіла, рівні глюкози, інсуліну та у моделі гомеостазу інсулінової резистентності. Таким чином, програма LiSM10 ефрективно поліпшила метаболічні показники, пов'язані з інсуліновою резистентністю, у чоловіків середнього віку.

Висновки. Донедавна було виконано численні дослідження вітчизняними та зарубіжними вченими, які були присвячені побудові та ефективності реабілітаційного процесу офрісних працівників різних вікових груп з різними проявами «офрісного синдрому». Та в жодному з них не описано комплексну програму реабілітаційного 
втручання для осіб, які страждають проявами цього синдрому.

Як правило, виконані окремі наукові дослідження стосуються побудови програм фрізичної терапії офісних працівників із больовими синдромами, порушеннями АТ, обміну речовин чи зору. Не описується наявність інших патологій, мультидисциплінарний підхід до фрізичної терапії

\section{Література}

1. Афранасьєв СМ. Профрілактика первинної інвалідності внаслідок захворювань і травм опорно-рухового апарату засобами фрізичної реабілітації [Prevention of primary disability due to diseases and injuries of the locomotorium by means of physical rehabilitation]. Дніпро: Журфонд; 2017. 259 с.

2. Герцик А. Теоретико-методичні основи фрізичної реабілітації / фрізичної терапії при порушеннях діяльності опорнорухового апарату [Theoretical and methodological foundations of physical rehabilitation / physical therapy for disorders of the musculoskeletal system] [монографія]. Львів: ЛДУФК, 2018. 388 с.

3. Камчатнов ПР, Чугунов АВ, Умарова ХЯ. Комбинированная терапия скелетно-мышечных болевых синдромов у офисного работника [Combined musculoskeletal pain syndrome therapy for an office worker]. Медицинский совет. 2012; 8: 55-8.

4. Терещенко ПС, Гвоздецький ВА, Назаренко ВІ. Фактори виробничого середовища та поширеність хронічних захворювань ЛОР-органів серед працівників сучасних офрісів [Factors of the production environment and prevalence of chronic diseases of ENT organs among employees of modern offices]. Журнал вушних, носових і горлових хвороб. 2014; 2: 79-82.

5. Maruyama C, Kimura M, Okumura $\mathrm{H}$ et al. Effect of a worksite-based intervention program on metabolic parameters in middle-aged male white-collar workers: A randomized controlled trial. Preventive Medicine. - 2010; 51: 11-17.

helenkal972@gmail.com тематичного контингенту чи комплексність реабілітаційних заходів.

Перспективи подальших досліджень. Вважається, що перспективними є розробка та впровадження комплексної програми фрізіотерапевтичного втручання відповідно до існуючих міжнародних стандартів (ICF, ICHI) для осіб працездатного віку із проявами офрісного синдрому.

6. Go S-U, Lee B-H. Effects of manual therapy on shoulder pain in office workers. Journal of Physical Therapy Science. 2016; 28: 2422-2425.

7. Kormiltsev $\mathrm{V}$. The dynamic of heart rate variability under the physical rehabilitation process in office workers with low back pain. Теорія і методика фрізичного виховання і спорту. 2014;2: 89-92.

8. Sethi J. Effect of Body Mass Index on work related musculoskeletal discomfort and occupational stress of computer workers in a developed ergonomic setup. Sports Medicine, Arthroscopy, Rehabilitation, Therapy \& Technology. 2011; 3: 22-29.

9. Sihawong R, Janwantanakul P, Jiamjarasrangsic W. Effects of an exercise programme on preventing neck pain among office workers: a 12-month cluster-randomised controlled trial. Occupational and Environmental Medicine. 2013;71: 63-70.

10. Yoo C, Park S, Yang D et al. Study of the Physical Condition of Middle-aged Office and Field Workers Aged 50 and Older. Journal of Physical Therapy Science. 2014; 26: 1575-77.

11. Nejati P, Lotfiyan S, Moezy A, Nejati M. The relationship of forward head posture and rounded shoulders with neck pain in Iranian office workers. Med J Islam Repub Iran. 2014; 40: 28-26. URL: https://www.ncbi.nlm.nih.gov/pmc/articles/PMC4154278/ pdf/mjiri-28-26.pdf

12. Waters TR, Dick RB. Evidence of Health Risks Associated with Prolonged Standing at Work and Intervention Effectiveness. Rehabilitation Nursing. 2014; 40:148-165.

Надійшла 12.11.2019 